\title{
Communication/Comunicação
}

\section{PCR-RFLP of 165 ribosomal DNA to confirm the identification of Enterococcus gallinarum and Enterococcus casseliflavus isolated from clinical and food samples}

\author{
PCR-RFLP do 16S DNA ribossomal para confirmar a identificação de Enterococcus gallinarum \\ e Enterococcus casseliflavus isolados de amostras clínicas e alimentares
}

\author{
Aline Weber Medeiros ${ }^{1}$, Pedro d'Azevedo ${ }^{2}$, Rebeca Inhoque Pereira ${ }^{3}$, Ana Paula Cassenego ${ }^{1}$, Sueli Van Der Sand ${ }^{3}$, \\ Jeverson Frazzon ${ }^{4}$ and Ana Paula Guedes Frazzon ${ }^{3}$
}

\begin{abstract}
Introduction: This study aimed to confirm the identification of Enterococcus gallinarum and Enterococcus casseliflavus isolated from clinical and food samples by PCR-RFLP. Methods: Fifty-two strains identified by conventional biochemical exams were submitted to PCR amplification and digested with HinfI. Only 20 (38.5\%) of the 52 strains showed a DNA pattern expected for E. gallinarum and E. casseliflavus. Results: Analysis of the results of this study showed that E. gallinarum and E. casseliflavus are occasionally erroneously identified and confirmed the potential application of $16 \mathrm{~S}$ rDNA analysis for accurate identification of these species. Conclusions: A correct identification is important to distinguish between intrinsic and acquired vancomycin resistance.
\end{abstract}

Key-words: PCR-RFLP of $16 \mathrm{~S}$ rDNA. Enterococcus gallinarum. Enterococcus casseliflavus.

\section{RESUMO}

Introdução: O objetivo deste estudo foi confirmar a identificação de amostras clínicas e alimentos de Enterococcus gallinarum e Enterococcus casseliflavus por PCR-RFLP. Métodos: Cinquenta e duas cepas identificadas por exames bioquímicos convencionais foram submetidos a amplificação por PCR e digestão com Hinfl. Apenas 20 (38,5\%) das 52 amostras apresentaram um padrão de DNA esperado E. gallinarum e E. casseliflavus. Resultados: Analise dos resultados deste estudo demonstraram que, algumas vezes E. gallinarum e E. casseliflavus são erroneamente identificados e confirmaram a potencial aplicação da análise do $16 \mathrm{~S}$ rDNA para identificação exata destas espécies. Conclusões: A correta identificação é importante a fim de distinguir entre resistência intrínseca e adquirida à vancomicina.

Palavras-chaves: PCR-RFLP de 16S rDNA. Enterococcus gallinarum. Enterococcus casseliflavus.

1. Graduate Program of Agricultural and Environmental Microbiology, Federal University of Rio Grande do Sul, Porto Alegre, RS, Brazil. 2. Department of Basic Health Sciences, Microbiology Department, Federal Health Sciences University of Porto Alegre, Porto Alegre, RS, Brazil. 3. Microbiology Department, Federal University of Rio Grande do Sul, Porto Alegre, RS, Brazil. 4. Science and Food Technology Institute, Federal University of Rio Grande do Sul, Porto Alegre, RS, Brazil.

Address to: Dr. Ana Paula Guedes Frazzon. ICBS/UFRS. Campus do Centro. Av. Sarmento Leite 500/ sala 158, 90050-170 Porto Alegre, RS.

Tel: 5551 3308-4111; Fax: 5551 3308-4111

e-mail: ana.frazzon@ufrgs.br

Received in 16/11/2009

Accepted in 13/01/2010

\section{INTRODUCTION}

Enterococci are opportunistic pathogens and well known as the principal microorganisms associated with the development of infections, especially in immunosuppressed patients. Furthermore, strains have been recognized as emerging human pathogens mostly associated with nosocomial infections ${ }^{1}$. The emergence of enterococci in nosocomial infections has grown in parallel with the rise in strains resistant to a large number of antimicrobial drugs used in the treatment of human infections. Enterococcus gallinarum and Enterococcus casseliflavus exhibit low-level intrinsic resistance to vancomycin, conferred by the van $\mathrm{C}-1$ gene $^{2}$. Commercial kits for species identification of Enterococcus are unable to distinguish E. gallinarum and E. casseliflavus from other enterococci ${ }^{3}$. Rapid and reliable differentiation of these species in patients infected with vancomycin resistant enterococci (VRE) is essential for an infection control program. The aim of this work was to confirm the identification of E. gallinarum and E. casseliflavus using the PCR-restriction fragment length polymorphism (PCR-RFLP) technique.

\section{METHODS}

In the current study, E. gallinarum $(\mathrm{n}=32)$ and E. casseliflavus $(\mathrm{n}=20)$ isolated from clinical samples and food identified by conventional biochemical were analyzed. Two references strains E. gallinarum (PAD 262) and E. casseliflavus (PAD 71) were obtained from the culture collection at the laboratory of microbiology of the Federal University of Health Sciences (Universidade Federal de Ciências da Saúde) of Porto Alegre and used as controls (Table 1). Extraction of total DNA from cells followed the method described by Riboldi et al ${ }^{4}$ The amplifications were performed with a thermal 
Table 1. Enterococcus gallinarum and Enterococcus casseliflavus isolated from clinical and food samples in South Brazil.

\begin{tabular}{lcc}
\hline \multirow{2}{*}{ Species (number of isolates) } & \multicolumn{2}{c}{ Genotype by PCR-RFLP } \\
\cline { 2 - 3 } & Positive (\%) & Negative (\%) \\
\hline Enterococcus gallinarum PAD $1262^{*}(1)$ & $1(100 \%)$ & 0 \\
Enterococcus casseliflavus PAD 71*(1) & $1(100 \%)$ & 0 \\
Enterococcus gallinarum (32) & $15(47 \%)$ & $17(53 \%)$ \\
Enterococcus casseliflavus (20) & $5(25 \%)$ & $15(75 \%)$ \\
\hline Total & $\mathbf{2 2}$ & $\mathbf{3 2}$ \\
\hline
\end{tabular}

* PAD culture collection at the Laboratory of Microbiology of Federal University of Health Sciences of Porto Alegre.

cycler (Eppendorf Mastercycler Personal). The primers 16Sent-F (5'-CTGACGCTGAGGCTCGAAAGCG-3') and 16Sent-R (5'-TGTGACGGGCGGTGTGTACAAGGGGG-3') corresponded to nucleotide sequences of $16 \mathrm{SrDNA}$ of the genus Enterococcus. The PCR product of $661 \mathrm{bp}$ amplified was submitted to digestion with the restriction enzyme HinfI (Jena Bioscience GmbH, Germany), according to the manufacturer's instructions. The DNA fragments obtained were resolved by electrophoresis on $2 \%$ agarose gel stained by ethidium bromide.

\section{RESULTS AND DISCUSSION}

The PCR-RFLP results from reference strains of E. gallinarum and E. casseliflavus showed two distinguishable DNA fragments of $589 \mathrm{bp}$ and $72 \mathrm{bp}$ (Figure 1). PCR-RFLP from the 52 strains tested demonstrated that $47 \%(15 / 32)$ of E. gallinarum and $25 \%(5 / 20)$ showed the expected PCR-RFLP patterns (Figure 1). Two PCRRFLP positive E. gallinarum and one E. casseliflavus were analyzed

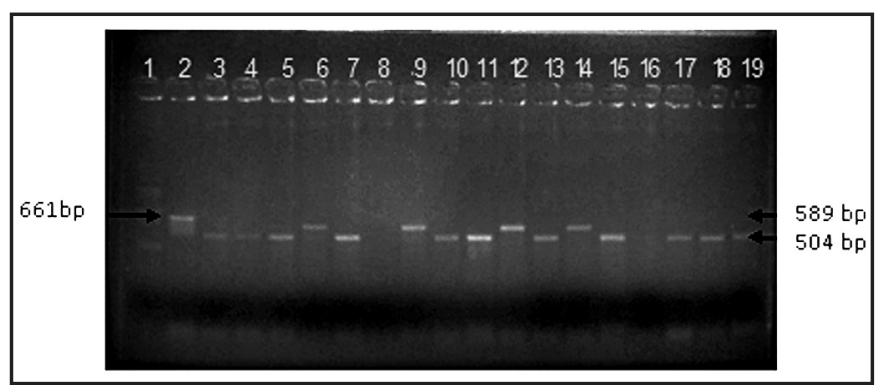

FIGURE 1 - Restriction DNA fragments obtained with the digestion of PCR amplification products with the enzyme HinfI. (1) Ladder $100 \mathrm{bp}$; (2) PCR product from E. gallinarum non digested; (3) E. gallinarum PAD 1262; (4) E. casseliflavus PAD 71; (5) E. galllinarum clinical isolate; (6) misidentified E. gallinarum clinical isolate; (7) E. casseliflavus clinical isolate; (8) Negative control; (9) misidentified E casseliflavus clinical isolate; (10-11) E. casseliflavus isolated from food; (12) misidentified E. casseliflavus isolated from food; (14) E. gallinarum isolated from food; (15-19) misidentified E. gallinarum isolated from food. by the SDS-PAGE method and confirmed the results obtained. On the other hand, 53\% (17/32) of E. gallinarum and 75\% (15/20) of E. casseliflavus strains showed three DNA fragments of 504, 85 and $72 \mathrm{bp}$ (Figure 1). These strains were resubmitted to a new set of biochemical tests and reclassified as: E. faecium, E. faecalis and Enterococcus sp. The 16S rDNA gene has been useful for the identification of Enterococcus genus and species ${ }^{5,6}$. All 16S rDNA sequences deposited in GenBank of the NCBI of E. gallinanum and E.casseliflavus have a conserved thymidine $(\mathrm{T})$ at position 1248 , while other species of enterococci predominantly present a cytosine (C) or $\mathrm{T}$ at the equivalent position. A single conserved base substitution in this position in E. gallinarum and E. casseliflavus eliminates the restriction endonuclease site for Hinfl. The present results demonstrate that E. gallinarum and E. casseliflavus are occasionally erroneously identified and confirmed the potential application of $16 \mathrm{~S}$ rDNA analysis to accurately identify these species. Correct identification is very important to discriminate between natural and VRE strains.

\section{CONFLICT OF INTEREST}

The authors declare that there is no conflict of interest.

\section{FINANCIAL SUPPORT}

The authors grateful to the Conselho Nacional de Desenvolvimento Científico e Tecnológico, the Coordenação de Aperfeiçoamento de Pessoal de Nivel Superior and the Fundação de Amparo a Pesquisa do Rio Grande do Sul for their financial support.

\section{REFERENCES}

1. d'Azevedo PA, Dias CA, Teixeira LM. Genetic diversity and antimicrobial resistance of enterococcal isolates from Southern region of Brazil. Rev Inst Med Trop São Paulo 2006; 48,11-16.

2. Clark NC, Teixeira LM, Facklam RR, Tenover FC. Detection and differentiation of van C-1, van C-2and van C-3, glycopeptide resistance genes in enterococci. J Clin Microbiol 1998; 36: 2294-2297.

3. Facklam RR, Carvalho MGS, Teixeira LM. History, taxonomy, biochemical characteristics, and antibiotic susceptibility testing of enterococci. In The enterococci: pathogenesis, molecular biology, and antibiotic resistance. Eds, Washington: ASM Press; 2002. p 1-54.

4. Riboldi GP, Frazzon J, d'Azevedo PA, Frazzon APG. Antimicrobial resistance profile of Enterococcus spp isolated from food in Southern Brazil. Braz J Microbiol 2009; 40:125-128.

5. Fortina MG, Ricci G, Borgo F, Manachini PL. Rapid identification of Enterococcus italicus by PCR with primers targeted to $16 \mathrm{~S}$ rRNA gene. Lett Appl Microbiol 2007; 44:443-446

6. Patel R, Piper KE, Rouse MS, Steckelberg JM, Uhl JR, Kohner P, et al Determination of $16 \mathrm{~S}$ rRNA sequences of enterococci and application to species identification of nonmotile Enterococcus gallinarum isolates. J Clin Microbiol 1998; 36: 3399-3407 